\title{
ПРОЦЕС ВИСТОЮВАННЯ ТІСТОВИХ ЗАГОТОВОК ЯК ОБЕ'КТ УПРАВЛІННЯ
}

\author{
Леонтьсва I.O., Хобін В.А.
}

Одеська Національна Академія харчових технологій

ORCID: ${ }^{1}$ https://orcid.org/0000-0003-4276-6744, ${ }^{2}$ https://orcid.org/0000-0003-0238-8371

E-mail: ${ }^{1}$ romashka.leontieva.92@ukr.net, ${ }^{2}$ khobin@onaft.edu.ua

Copyright (C) 2018 by author and the journal "Automation technologies and business - processes. This work is licensed under the Creative Commons Attribution International License (CC BY). http://creativecommons.org/licanses/by/4.0

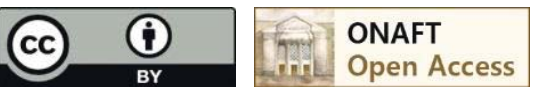

DOI: $10.15673 /$ atbp.v10i1.874

\begin{abstract}
Анотація: Прочес вистоювання тістових заготовок складається з багатьох фізико-механічних та біохімічних процесів, щзо ускладнюе управління та отримання оптимальних показників якості на виході готового продукту. Велика кількість регульованих змінних та інформаційних потоків впливає на хід протікання процесу дозрівання тіста. У шафах (камерах вистоювання) підтримується строгий температуро-вологісний режим. Важливо не тільки з високою точністю підтримувати температуру в межах 35-40 ${ }^{\circ} \mathrm{C}$, а вологість 75-85\%, але $i$ регулювати ияі параметри для оптимізації процесу вистоювання в залежності від виду виробів, які виготовляються. Під впливом температури в шафі вологість з поверхні виробу випаровується одночасно з прочесом розпушення тіста в обсязі під впливом СО2 в результаті спиртового бродіння. В даній статті розглядаються способи прискорення дозрівання тіста та пропонується введення додаткового каналу управління, який відображатиме інтенсивність газоутворення під час спиртового бродіння, а саме визначатиме приріст об' єму тістової заготовки на етапі вистоювання з метою підвищення якості хлібобулочних виробів. Завдяки камерам відеоспостереження додатково контролюватиметься об'єм тістової заготовки. Саме це дозволить встановити оптимальний час вистоювання для того чи іншого виду хлібобулочних виробів. Камери відеоспостереження зможуть ідентифікувати в периу чергу приріст висоти тістової заготовки. Отримана інформація по даному каналу буде передаватися до лабораторії з метою швидкого реагування, використовуючи найоптимальніший варіант прискорення процесу дозрівання тіста.

Annotation: The process of standing of dough purveyances consists of many physical, mechanical and biochemical processes, that complicates a management and receipt of optimal indexes of quality on the return of the prepared product. Plenty of the managed variables and dataflows influences on motion of flowing of process of ripening of dough A strict temperature-humidity regime is carried in the cabinets (cooling rooms). It is important not only to maintain the temperature within $35-40^{\circ} \mathrm{C}$ and the humidity within $75-85 \%$ to a high precision. But also it is important to regulate these parameters for optimizing the pouring process depending on the type of products being manufactured. Under the influence of the temperature in the cabinet, the moisture from the product's surface steams off simultaneously with the process of the dough dilution in volume under the influence of $\mathrm{CO} 2$ as a result of alcohol fermentation. The methods of acceleration of ripening of dough are examined in this article, and introduction of secondary channel of management, that will display intensity of gasification during a spirit fermentation, namely determine the increase of volume of micmoвoï purveyance on the stage of standing with the aim of upgrading of bakegoodss, is offered. In consequence of the cameras, video observation will further control the volume of dough work. This is precisely what will allow you to set the optimal time for a particular kind of bakery products. Surveillance cameras will be able to identify in primarily the increase in the height of the dough product. The received information on this channel will be transmitted to the laboratory for the purpose of rapid response, using the most optimal version of the dough maturation process acceleration.
\end{abstract}

Ключові слова: час вистоювання, заміс тіста, спиртове бродіння, об'єм тістової заготовки.

Key words: time of stand, dough, alcohol fermentation, volume of dough preparation.

\section{Вступ}

В процесі виробництва хлібобулочних виробів остаточне вистоювання тістових заготовок $є$ найважливішою стадією технологічного процесу. В процесі вистоювання тіста будь-які відхилення технологічних змінних від їх регламентованих значень (відхилення температури в камері вистоювання і вологості пароповітряного середовища від оптимального рівня, збільшення або зменшення часу знаходження тістових заготовок в камері вистоювання і ін.) безпосередньо позначаються на якості готових виробів. 


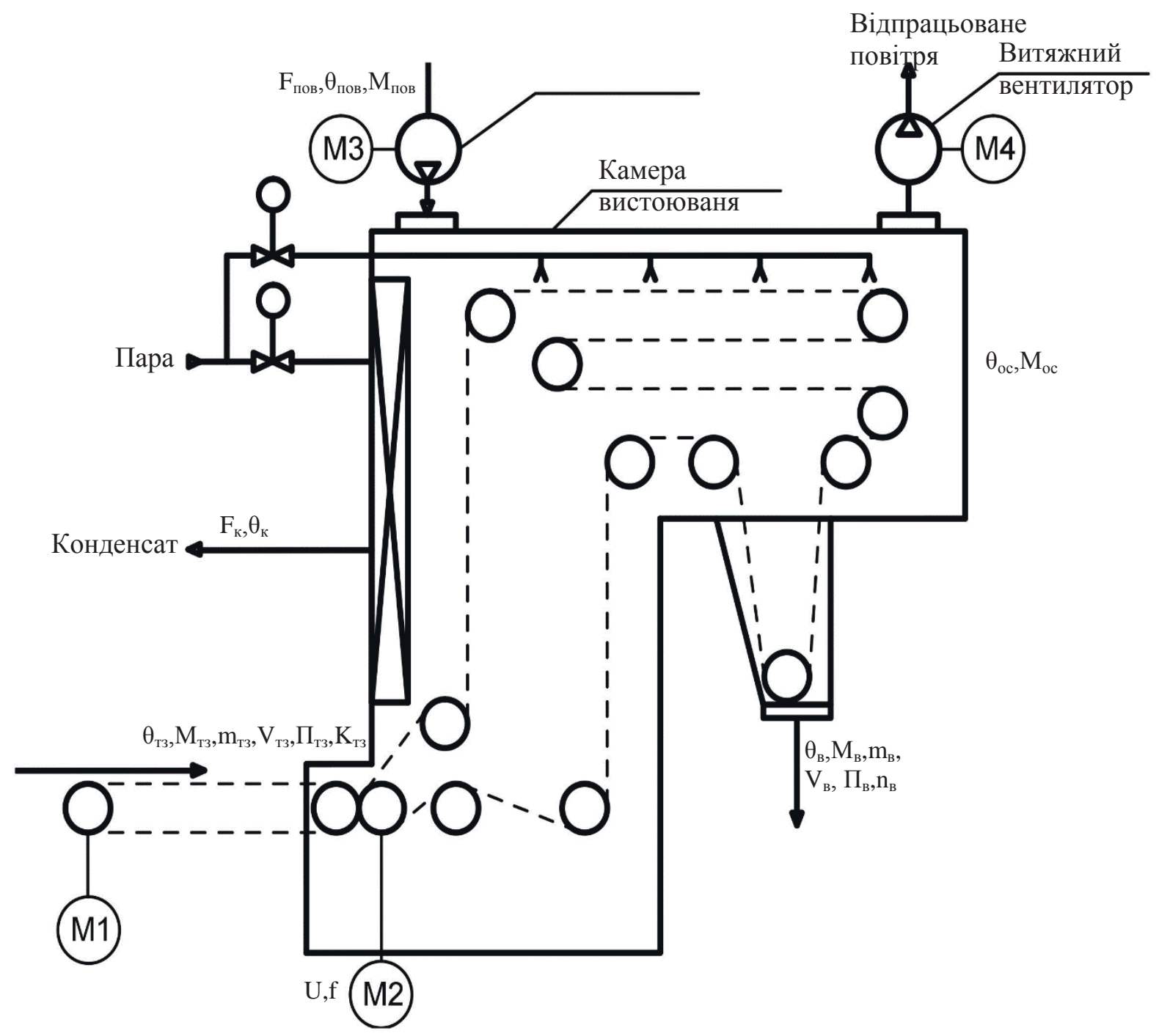

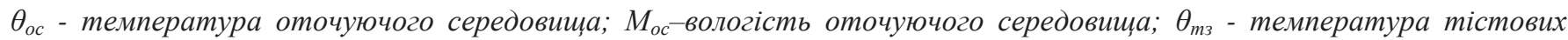

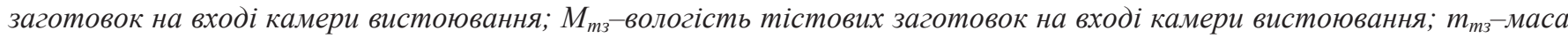
тістових заготовок на вході камери вистоювання; $V_{\text {тз }}-$ об' 'м тістових заготовок на вході камери вистоювання; П - пористість тістових заготовок на вході камери вистоювання; $K_{\text {тз }}$ кількість тістових заготовок на вході камери

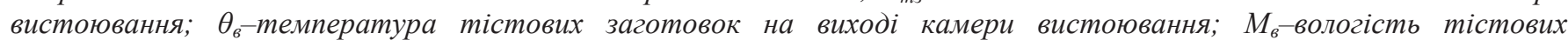
заготовок на виході камери вистоювання; $m_{в}$-маса тістових заготовок на виході камери вистоювання; $V_{\text {в }}$ об'єм тістових заготовок на виході камери вистоювання; П - пористість тістових заготовок на виході камери вистоювання; $n_{6}$ - кількість тістових заготовок на виході камери вистоювання; $\theta_{\kappa в}$ - температура в камері

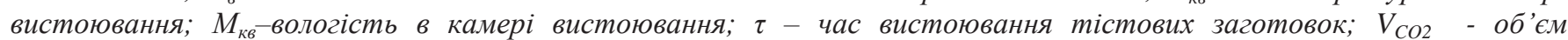
вуглекислого газу в камері вистоювання; $F_{n}$-витрати пари; $P_{n}-$ тиск пари в магістралі; $\theta_{\kappa}-$ температура конденсату; $F_{\kappa}-$ витрати конденсату; $F_{n о в}-$ витрати повітря; $\theta_{\text {пов }}-$ температура повітря; $M_{\text {пов }}-$ вологість повітря; $F_{6 n}$ - витрати відпрацьованого повітря; $\theta_{\text {вп }}$ - температура відпрацььованого повітря; $M_{6 n}-$ вологість відпрацьованого повітря; $U_{1}$ - положення регулюючого органу подачі пари до нагрівача камери вистоювання; $U_{2}-$ положення регулюючого органу подачі пари до камери вистоювання; $U, f$ - параметри двигунів; $S_{m з}-$ швидкість переміщення тістової заготовки

\section{Рис. 1.1 - Параметризована технологічна схема процесу вистоювання тістових заготовок}

Чому так важливий етап вистоювання?

Під час вистоювання в тістових заготовках йде інтенсивний процес бродіння, в результаті якого[1,2]:

- відбувається відновлення і подальший розвиток пористості (обсяг тістових заготовок в середньому збільшується в 2,5-3 рази);

- тісто збагачується комплексом речовин, необхідних для формування смаку і аромату;

- поліпшуються фізико-механічні та хімічні властивості тіста, що сприяють гарному пропікання м'якушки i отримання оптимального кольору скоринки; 
- заготовки набувають необхідну форму.

\section{Суть ТП вистоювання тістових заготовок і задача ефективного управління процесом}

Розглянемо технологічну схему процесу вистоювання тістових заготовок рис.1.1 [3]. Час вистоювання тістових заготовок безпосередньо залежить від: температури в камері вистоювання - $\theta_{\kappa \varepsilon}$; маси тістових заготовок - $m_{m з}$; рецептури, вологості в камері - $M_{\kappa \varepsilon}$, температури тіста - $\theta_{m з}$, ступеня бродіння і характеру механічної обробки тіста; особливостей борошна, способу вистоювання заготовок (в хлібопекарських формах або без форм); планованої температури випічки заготовок і навіть від того, який вид ми хочемо надати готовим виробам. Зважаючи не те, що особливості борошна, планову температуру випікання, вологість, температуру, характер механічної обробки ми можемо ціленаправлено задавати, коригувати та змінювати, то залишається відкритим питання впливу інтенсивності бродіння на збільшення об'єму тістових заготовок. Відомо, що чим інтенсивніше проходить спиртове бродіння, тим швидше проходить вистоювання[2,3].

Відомо досить багато способів управління процесом вистоювання тістових заготовок, але всі вони грунтуються на контролі трьох параметрів таб.1 [2]:

Таблиця 1

\begin{tabular}{|c|c|}
\hline Регламентовані змінні & $\begin{array}{c}\text { Допуски зміни регламентованих } \\
\text { змінних }\end{array}$ \\
\hline (на прикладі деяких видів пшеничного хліба) & $32-42{ }^{\circ} \mathrm{C}$ \\
\hline Вологість повітря в камері вистоювання & 75 до $85 \%$ \\
\hline Час перебування тістових заготовок в камері вистоювання & $30-120$ мин \\
\hline
\end{tabular}

Для прискореного дозрівання і бродіння тіста застосовують (в різній комбінації) наступне: збільшують дозування дріжджів, опари (закваски), інтенсифікують заміс тесту, підвищують початкову температуру тіста, додають поліпшувачі. Розглянемо їх більш детально [1,2]:

- Збільшення дозування дріжджів або активація дріжджів, взятих за нормою на заміс опари або тесту, інтенсифікує процес дозрівання тіста.

- Підвищення дозування опари (закваски) на приготування тіста збільшує число дріжджів і молочнокислих бактерій в тісті, зміст кислот, набряклих білків і продуктів протеолізу.

- Інтенсивний заміс тесту послаблює структуру білкових речовин і крохмалю, інтенсифікує процеси бродіння і дозрівання тіста. Інтенсивний заміс тіста прискорює бродіння на 20-60 \% та підвищує температуру тістової заготовки.

- Підвищення початкової температури тесту до температури $32-33^{\circ} \mathrm{C}$ значно прискорює процеси дозрівання, проте підвищення температури до $34-35^{\circ} \mathrm{C}$ негативно діє на дріжджі і послаблює клейковину.

- Додавання покращувачів (амілолітичні ферментні препарати, неферментований солод, цукор і ін.) Стимулює цукрово-і газоутворення в тісті.

\section{Основна частина}

У шафах (камерах вистоювання) підтримується строгий температуро-вологісний режим. Важливо не тільки 3 високою точністю підтримувати температуру в межах $35-40{ }^{\circ} \mathrm{C}$, а вологість 75-85\%, але і регулювати ці параметри для оптимізації процесу вистоювання в залежності від виду виробів, які виготовляються. Під впливом температури в шафі вологість з поверхні виробу випаровується одночасно з процесом розпушення тіста в обсязі під впливом СО2.

Спиртове бродіння. Збудниками спиртового бродіння є дріжджі - сахароміцети Saccharomyces cerevisial. Це анаеробний процес перетворення глюкози і фруктози під дією ферментів дріжджової клітини через низку проміжних фаз у спирт і диоксид вуглецю. Сумарна рівновага спиртового бродіння описується рівнянням Гей-Люссака[2]:

$$
\mathrm{C}_{6} \mathrm{H}_{12} \mathrm{O}_{6}=2 \mathrm{C}_{2} \mathrm{H}_{5} \mathrm{OH}+2 \mathrm{CO}_{6}+94 \text { кДж (28ккал) }
$$

Так, $з$ підвищенням температури 326 до $35{ }^{\circ} \mathrm{C}$ інтенсивність газоутворення зростає в 2 рази. Саме тому було запропоновано ведення додаткового каналу, що збільшення об'єму тістових заготовок. Тому що саме по кількості та швидкості виділення вуглекислого газу можна судити про інтенсивність протікання біохімічних процесів в клітинах тіста. Розглянемо рис.1.2. 


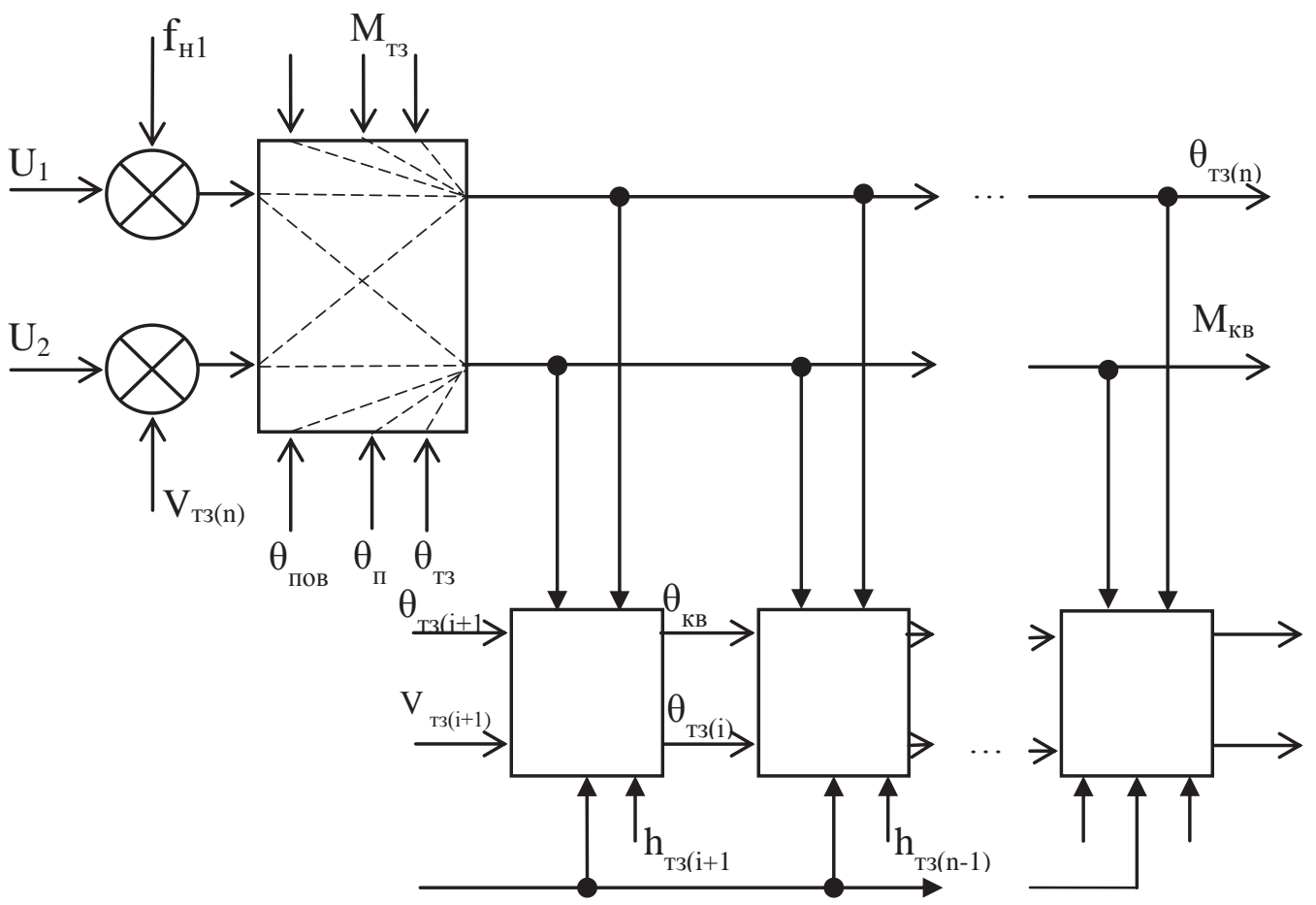

$\theta_{\text {mз }}-$ температура тістових заготовок; $M_{m з}-$ вологість тістових заготовок; т $\theta_{n}-$ температура пара; $M_{n}-$

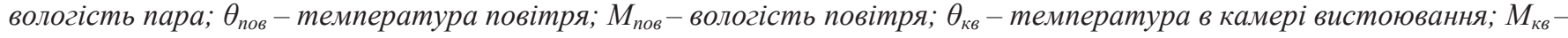
вологість в камері вистоювання; $V_{\text {тз }}$-об'єм тістової заготовки; $S_{m з}-$ швидкість перемішення тістової заготовки; $h_{m з}$ - висота тістової заготовки; $\tau$ - час вистоювання тістових заготовок; $U_{1}-$ положення регулюючого органу подачі пари до нагрівача камери вистоювання; $U_{2}$ - положення регулюючого органу подачі пари до камери вистоювання; $f_{н}$ - вектор неконтрольованих збурень;

$$
\Phi(i)-V_{m 3(i+1)}=0.513 \cdot d^{2} \cdot h_{m 3(i)} \cdot k, \quad(i=0) \quad[4]
$$

Рис. 1.2 - Структурна схема процесу вистоювання тістових заготовок як об'скта регулювання

\section{Висновки}

Завдяки камерам відеоспостереження ми зможемо додатково контролювати приріст об'єма тістової заготовки. Саме це дозволить встановити оптимальний час вистоювання для того чи іншого виду хлібобулочних виробів. Камери відеоспостереження зможуть ідентифікувати в першу чергу приріст висоти тістової заготовки. Що дасть можливість визначати об'єм тістової заготовки. Vт - об'єм тістової заготовки; h - висота тістової заготовки; $\mathrm{k}$ - коефіцієнт, який враховує форму хліба; $\mathrm{k}=1.09 ; \mathrm{d}$ - діаметр тістової заготовки, м.

$$
\mathrm{VT}=0.513 \cdot \mathrm{d} 2 \cdot \mathrm{hT} 3(\mathrm{i}) \cdot \mathrm{k}, \quad(\mathrm{i}=0)
$$

Отримана інформація по даному каналу буде передаватися до лабораторії 3 метою швидкого реагування, використовуючи найоптимальніший варіант прискорення процесу дозрівання тіста.

\section{Список використаних джерел}

[1] Харчові технології. Дозрівання тіста. [Електронний ресурс] - Режим доступу до ресурсу: http://foodtecnology.info/tehnologiya-hliba-makaronnih-kondite/tehnologiya-virobnitstva-hliba/dozrivannya-tista

[2] Злобин Л.А. Оптимизация технологических процессов хлебопекарного производства 1987. - С. 53-58.

[3] Хобин В. А. Системы гарантирующего управления технологическими агрегатами: основы теории, практика применения //Одесса: ТЕС. - 2008. - Т. 306.

[4] А. Германчук, В. Теличкун, Ю. Теличкун, М. Десик. Исследование тепло-масообменных процессов в камере гигротермической обработки тестовых заготовок Научни трудове на русенская университет, 2012, т.51, серия 9.2

\section{References}

[1] Food Technology. Maturing the dough. [Online]. Available at: http://foodtecnology.info/tehnologiya-hlibamakaronnih-kondite/tehnologiya-virobnitstva-hliba/dozrivannya-tista.

[2] L.A. Zlobin «Optimization of technological processes of baking production», p. 53-58, 1987.

[3] V. A. Hobin, "Sistemyi garantiruyuschego upravleniya tehnologicheskimi agregatami: osnovyi teorii, praktika primeneniya" in Odessa: TES, vol. 306, 2008.

[4] A. Germanyuk, V.Telichukun, Y.Telichukun, M.Desik. «Investigation of heat-mass-exchange processes in a chamber of hygrothermic treatment of test blanks», Scientific work on Russian University, vol.51, series 9.2, 2012. 